emergencies. EDs not only perform triage, provide treatment, and determine the disposition of immediately surviving injured victims, they also provide prehospital medical control, manage medical resources, solve logistical problems, and help calm a terrified public. All of these functions must be based on a clear understanding of the mechanisms, types, frequency, severity, and time course of injuries in terrorist bombings and a familiarity with the many lessons learned from past responses to terrorist bombing disasters.

This presentation reviews the epidemiology of masscasualty terrorist bombings and discusses the implications for ED response. Although it is prudent to "expect the unexpected," a rational approach to disaster management incorporates what is already known into the basis for planning and preparedness. As long as terrorists continue to use explosions to achieve their goals, terrorist bombings must remain a focus of medical disaster preparedness.

References

1. Terror Attack Database. International Policy Institute for Counter-Terrorism Web Site. Available at:

http://www.ict.org.il/. Accessed August 1, 2003.

Keywords: bombing; disaster; emergency department (ED); explosion; mass casualty; terrorism

Prehosp Disast Med 2003:18:s(1)s27.

E-mail: Arnoldmdes@cs.com

\section{Terrorism, et al.}

Marvin L. Birnbaum, $M D, P h D$

Professor of Medicine and Physiology, University of Wisconsin-

Madison, USA; Editor-in-Chief, Prehospital and Disaster

Medicine, World Association for Disaster and Emergency

Medicine

A new medical/public health definition of "terrorism" has been proposed:

The intentional use of violence-real or threatened- against one or more non-combatants and/or those services essential for or protective of their health, resulting in adverse health effects in those immediately affected and their community, ranging from a loss of well-being or security to injury, illness, or death.

Given this definition, it should be clear that, medically, acts of terrorism are conducted to induce fear and insecurity in the target population. Thus, the impact of an act of terrorism not only produces damage in the form of death and physical injury, but also results in profound psychosocial effects upon the directly affected population and also on the world community in the form of terror, fear, and post-traumatic stress disorders. The acts of 11 September 2001 (9/11), although medically manageable at the time, are now producing a medical disaster, as the ongoing psychosocial effects threaten to overwhelm the medical community and require substantial outside assistance.

Following $9 / 11$, the responses to terrorism at an international level have resulted in the provision of vast amounts of resources supposedly directed toward the prevention of such events and toward the enhancement of our ability to respond if and when they do occur. In the United States, huge sums of money have been granted to the states to enhance their level of preparedness for the next major event. Unfortunately, little vision and guidance have accompanied these resources, and the funds are being spent in an uncoordinated fashion. There is little evidence that expending such funds have created enhanced preparedness.

Another problematic response to $9 / 11$ has been the government's periodic announcements that the threat level of terrorism has been raised or lowered, without providing any more specific information. This creates additional fear, which is unattached and psychologically disturbing. Such activities feed the underlying objectives of creating terror, fear, and insecurity. Over time, they also can induce complacency. Such activities are deleterious rather than helpful.

A positive aspect of this heightened awareness of terrorism is that in the past few years, we have been able to make more progress toward preparedness for all hazards than we have been able to achieve in disaster preparedness during the last half century! We have an unprecedented opportunity to enhance our preparedness and ability to respond to any hazard. After all, is the risk that a terrorist event will produce a massive number of casualties greater than that of any other kind of catastrophic event?

Keywords: 9/11; 11 September 2001; attacks; definition; fear; haz-

ards; impact; insecurity; preparedness; resources; terror; terrorism Prehosp Disast Med 2003;18:s(1)s27.

E-mail: mlb@medicine.wisc.edu

\section{Plenary Sessions}

\section{Civilian-Military Cooperation and the Use of Military Assets in Disaster and Humanitarian Relief Operations}

Knut Ole Sundnes, $M D$

Head, Office for War Surgery and Emergency Medicine, Norwegian Defence Forces; President, World Association for Disaster and Emergency Medicine

As a relatively new term, civilian-military cooperation (CIMIC) is but a new name for an aspect of the larger scope of civilian-military interrelationships. Such a civilian-military relationship covers a variety of scenarios, ranging from exclusively humanitarian assistance, or provision of peace-support operations, to war and occupation of a country. It's relatively recent in history (within the past 150 years) that these interrelationships have been "regulated" by conventions and international legislation. They now are governed by an increasing number of doctrines: Some are legally binding international conventions, others serve as rules of engagement for military alliances, and others represent ethically binding conventions and declarations.

The historical rationale for maintaining military forces has been for protection (defense) or for aggression (annexation). These may be fully professional armies with paid soldiers or drafted personnel doing compulsory military service. For both types, the core of the military is the combatants. But, except in peace-support operations, the same elements that provide support for the combatants are the assets most often called upon to provide humanitarian assistance, e.g., engineering support, logistics, and medical support. In fact, today the military is the only complete system that has the capacity to manage all manageable disasters. However, history serves as a serious obstacle for the 